Kamalasena B.D.T.M. \& Sirisena A.B.

Wayamba Journal of Management 12 (2)

\title{
Factors Influencing the Adoption of E-Learning by University Students in Sri Lanka: Application of UTAUT-3 Model during Covid-19 Pandemic
}

\author{
B.D.T.M. Kamalasena ${ }^{1} \&$ A.B. Sirisena ${ }^{2}$ \\ ${ }_{1,2}$ Department of Marketing \\ Faculty of Management and Finance \\ University of Ruhuna \\ SRI LANKA \\ amila@badm.ruh.ac.lk ${ }^{1}$, amila.b.sirisena@uia.no
}

\begin{abstract}
Universities around the world are entering 'emergency mode' during the COVID-19 pandemic, radically transforming education by switching towards online learning and other distance-based education methods. An unintended consequence of these emerging changes is that many students who are either not willing to use e-learning or have no adequate skills to learn through electronic devices or have no resources to access them are marginalized. Considering the timeliness and the relevance of the phenomenon, this study aims to identify the factors influencing the adoption of e-learning by Sri Lankan university students. The relevant data were collected through a self-administered questionnaire which was distributed among 191 university students based on the convenience sampling method. This study found out positive impacts of performance expectancy, facilitating conditions, habit, price-value, and personal innovativeness in IT on to use elearning. Moreover, the intention has a positive impact on the adoption of elearning platforms. This research fills the gap in the existing literature and provides valuable insights to the course administrators in universities in Sri Lanka to better manage e-learning systems.
\end{abstract}

Keywords-: E-learning, Unified Theory of Acceptance and Use of Technology 3 (UTAUT 3), Intention, Adoption 


\section{INTRODUCTION}

In most countries, the Covid-19 pandemic was declared a national emergency at the beginning of 2020. The pandemic compelled countries all over the world to adopt a series of mechanisms for emergency management (Zhang, Wang, Yang, \& Wang, 2020). Governments in various countries have initiated measures such as the lockdown of cities, the closure of educational institutes, and the execution of strict social distancing measures. The regime adopted during the pandemic has led business, science, cultural events, management, and education into online platforms (Sulkowski, 2020). This is a change in connection with technical and software infrastructure, but especially the development of social patterns and communication. This is further outlined by Kulikowski, et al., (2021) as the rapid expansion of COVID-19 has brought about major changes in dominant social lifestyles and communications.

The transition to the social online environment occurs extremely rapidly in the education sector (Leonardi, 2020). According to UNESCO monitoring, 192 countries have nationally closed educational institutes and 5 have implemented local closures which affect approximately $99.9 \%$ of the student population worldwide (UNESCO Report, 2020). The government of China has initiated a strategic move named "Suspending Classes without
Stopping Learning" (Zhang, Wang, Yang, \& Wang, 2020), and later on, governments of other countries also followed this resulting from the move to online education during the - closure of educational institutes. Schools and universities across the globe are transforming and altering education delivery methods radically by switching online, starting e-learning, and introducing online learning management systems (Hodges, et al., 2020; Tian, et al., 2020). As Dhawan, (2020) outlined, many academic institutions which were previously reluctant to change their traditional approach to pedagogy had no choice but to shift to online education.

As the traditional learning system shifted to e-learning, lecturers and students are exposed to new platforms including Microsoft teams, Zoom, and many more. To carry out lectures smoothly, the students were provided with proper protocols and guidelines for their adaptation to this new learning channel (Saxena, 2020). However, several research studies in the e-learning situation of students show that students have low attendance rates and a lack of intentions to learn (Chen, Wang, Wang, \& Zuo, 2021). This can be due to a number of challenges faced by both students and academicians when shifting from offline to online learning with a rapid transition. From the students' perspective, there are numerous technological problems, including download 
problems, issues in app installations, low internet speeds, login ID issues, unheard-of voice, and video, and so on (Ekanayake \& Weerasinghe, 2020; Andersson, 2008). Even more, students are bored and less interactive in elearning environments (Sangeeta \& Tandon, 2020). Therefore, the objective of this study is to comprehend the factors influencing the adoption of elearning by Sri Lankan university students during the Covid-19 pandemic thus the academicians and other administrators could take corrective action to make elearning more effective.

Even though e-learning in higher education institutions is continuously increasing, academic attention is being given to understanding the prospective context that falls behind the industry is lacking. Limited prior research studies are available on factors influencing e-learning in higher education institutes (eg: (Mei, et al., 2018; Mosunmola, et al., 2018; Tseng, et al., 2019), and even these were dealing with more incremental transitions of traditional learning to e-learning thus creating a gap in the literature on adoption of e-learning by students especially in current contexts (Chen, Wang, Wang, \& Zuo, 2021). Taking account of the timeliness and importance of the phenomenon, the current study focuses on identifying the factors influencing the adoption of elearning by Sri Lankan university students during the Covid-19 pandemic.

\section{LITERATURE REVIEW}

\subsection{E-learning in university education system in Sri Lanka}

E-learning could be defined as a process of learning facilitated by digital electronic tools and media (Basak, Wotto, \& Belanger, 2018) or electronically delivering a learning, training, or education program (Sangra, Vlachopoulos, \& Cabrera, 2012). E-learning involves using technology as a method of teaching (Wheeler, 2012) and using traditional methods in a new context of online communication. During the Covid-19 pandemic, using elearning methods using tools such as Zoom, Ms Teams, etc. extensively has caused serious changes to traditional patterns of communication between the teacher and the student (Shahzad, Hassan, Aremu, Hussain, \& Lodhi, 2021).

\subsection{Unified Theory of Acceptance and Use of Technology (UTAUT)}

The active information systems (IS) research stream represents individual acceptance and use of information technology (Venkatesh, Thong, \& Xu, Unified theory of acceptance and use of technology: A synthesis and the road ahead, 2016). In numerous previous studies, TAM and TPB were used to prevent IT adoption or use (Venkatesh, Thong, \& Xu, Unified theory of 
acceptance and use of technology: A synthesis and the road ahead, 2016). Venkatesh, et al., (2003) have summarized eight theories and models related to technology use namely theory of reasoned action (TRA) by Fishbein \& Ajzen, (1975), the social cognitive theory (SCT) by Bandura, (1986), the model of personal computer utilization (MPCU) by Thompson, et al., (1991), the technology acceptance model (TAM) by Davis (1986), the theory of planned behavior (TPB) by Ajzen, (1991), the innovation diffusion theory (IDT) by Moore \& Benbasat, (1991) the motivational model (MM) by Davis, et al., (1992) and the combined TAM and TPB by Taylor \& Todd, (1995) and proposed the UTAUT to examine the causal relations between several important constructs: performance expectancy, effort expectancy, social influence, facilitating conditions, intention to use e-learning systems, and technology use.

Later, Venkatesh, et al., (2012) expanded the UTAUT model to test information system acceptance in consumer settings with three additional constructs: hedonic motivation (HM), pricevalue $(\mathrm{PV})$, and habit (HB). The extended UTAUT was called UTAUT-2 with seven major drivers for information system adoption behavior.

\subsection{Unified Theory of Acceptance and Use of Technology-3 (UTAUT-3)}

The UTAUT-3 framework was introduced by Farooq, et al., (2017) to include eight determinants of technology acceptance as an extension of the UTAUT-2 model. Personal IT innovation has been added as the eighth construct. In predicting technological adoption, the authors of the UTAUT 3 model claim 66 percent of explanatory power.

\section{HYPOTHESIS DEVELOPMENT}

\subsection{Performance expectancy}

Performance expectancy is defined as a user's belief that targeted technology will improve his or her performance in order to achieve job-related gains (Venkatesh, Thong, \& Xu, Consumer acceptance and use of information technology: extending the unified theory of acceptance and use of technology, 2012). The following are the five different constructs and corresponding theories for the unification of performance expectancy: perceived usefulness (TAM/TAM2), job fit (MPCU), extrinsic motivation (MM), relatively advantage (IDT), and outcome expectations (SCT) (Patil, Tamilmani, Rana, \& 
Raghavan, 2020). As per the prior studies, performance expectancy is an important predictor of continued intention in blended learning or e-learning (Liaw , 2008). Most importantly, previous studies have identified performance expectancy as the strongest predictor of consumers' beliefs and intentions towards adopting a technology (Venkatesh, Thong, \& Xu, Consumer acceptance and use of information technology: extending the unified theory of acceptance and use of technology, 2012). Therefore, it is hypothesized,

H1: Performance expectancy has a positive impact on intention to use e-learning systems

\subsection{Effort expectancy}

Effort expectancy is defined as the ease associated with technology use (Venkatesh, Thong, \& Xu, Consumer acceptance and use of information technology: extending the unified theory of acceptance and use of technology, 2012). The following are three constructions that unify effort expectations: perceived ease of use (TAM/TAM2), complexity, and easiness of use (MPCU) (IDT). Al-Azawei \& Lundqvist, (2015) pointed out that students, particularly in non-compulsory courses, are unwilling to continue using the online systems if they encounter difficulties in using the online system. Moreover, Chen, et al., (2021) stressed that effort expectancy has a positive significant impact on continuous intention to use e-learning platforms among college students. Therefore, this study hypothesized that,

H2: Effort expectancy has a positive impact on intention to use e-learning systems

\subsection{Social influence}

Social influence is defined as the extent to which someone realizes how others think he or she should use a new information system (Venkatesh, Thong, \& Xu, Consumer acceptance and use of information technology: extending the unified theory of acceptance and use of technology, 2012). Social influence is equivalent to the subjective norm in TRA and image in IDT. The intention of an individual to use new technologies, as described in previous studies, is generated by social impact (Wang, et al., 2009; Yoo, et al., 2012; Wong \& Huang, 2015). Based on previous studies (e.g.: Venkatesh, et al., 2003; Salloum \& Shaalan, 2019) the social impact of e-learning is found to contribute significantly to behavioral intent and it is also learned how social influence affects the intention of behavior. Accordingly, this study hypothesized that,

H3: Social Influence has a positive impact on intention to use e-learning systems 


\subsection{Facilitating conditions}

As per Venkatesh, et al., (2012), the "facilitating conditions" are known as environmental factors or physical behaviors, which inspire a user to perform the tasks. Moreover, according to Venkatesh, et al., (2003), the impact of facilitating conditions was significant in the UTAUT model. Several previous studies such as Salloum \& Shaalan, (2019); Sangeeta \& Tandon, (2020) and Venkatesh, et al., (2012) have tested the impact of facilitating conditions on elearning and they found that there is a significant impact between facilitating conditions and intention to use e-learning. Consequently, researchers hypothesized that,

H4: Facilitating Conditions have a positive impact on intention to use e-learning systems

\subsection{Hedonic motivation}

Hedonic motivation is defined as the fun or desire of using technology and has proved to play an important role in determining acceptance and use of the technology (Venkatesh, Thong, \& $\mathrm{Xu}, 2012$ ). Proving that, prior studies such as Gunasinghe, et al., (2020), and Venkatesh, et al., (2012) have found that hedonic motivation is an important determinant of intention to use technology. Therefore, this study hypothesized that hedonic motivation has a positive significant impact on intention to use e-learning among university students in Sri Lanka.

H5: Hedonic Motivation has a positive impact on intention to use e-learning systems

\subsection{Price value}

From consumers' perspective, this variable appears to be valid where price-value refers to the cognitive trade between the perceived benefits of using technology and the amount spent on it (Venkatesh, Thong, \& Xu, 2012). When the perceived advantages are greater than perceived costs in consumer cognition, the price value is positive, which in turn has a positive effect on the intention to use the system or technology (Gunasinghe, Hamid, Khatibi, \& Azam, 2020). Accordingly, this research hypothesized that,

H6: Price-value has a positive impact on intention to use elearning systems

\subsection{Habit}

Habit is the extent to which a person acts unconsciously or automatically because of previous experience (Venkatesh, Thong, \& $\mathrm{Xu}, 2012)$. Moreover, Venkatesh, et al., (2012) outlined that, habit reflects experience, but the only experience is not enough to create a habit. Habit creates cognitive commitment to specific conduct and frequently prevents changes in actual behavior (Murray \& Häubl, 2007). Consequently, the researchers hypothesized that, 
H7: Habit has a positive impact on intention to use e-learning systems

\subsection{Personal innovativeness in} IT

Farooq, et al., (2017) have recognized personal innovativeness in IT as a stable characteristic that makes people desire to test new technology. Personal innovativeness affects both the intention of the user and the actual behavior. Moreover, several scholars have affirmed that personality characteristics such as personal innovativeness affect the adoption of technologies particularly in the domain of IT (Farooq, et al., 2017; Dutta, et al., 2015). Accordingly, it is hypothesized that,

H8: Personal innovativeness in IT has a positive impact on intention to use e-learning systems

\subsection{Intention to use and the}

\section{adoption of e-learning systems}

The intention for behavior is an essential factor of the UTAUT2 model which shows the desire and attempts of individuals to perform a particular behavior (Patil, Tamilmani, Rana, \& Raghavan, 2020). As per Ajzen, (1991) researchers suggest that the intention of individuals might capture different motivating factors of people that influence them to perform a behavior. Thus, stronger individual intentions resulted in a higher possibility of performing the underlying behavior. Prior research studies such as Tseng, et al., (2019) and Sangeeta \& Tandon, (2020) identified that intention has a positive significant impact on elearning adoption. Considering those studies, this study hypothesized that,

H9: Intention to use e-learning systems has a positive impact on e-learning systems adoption

such as Tseng, et al., (2019) and Sangeeta \& Tandon, (2020) identified that intention has a positive significant impact on elearning adoption. Considering those studies, this study hypothesized that,

H9: Intention to use e-learning systems has a positive impact on e-learning systems adoption

\section{METHODS}

This research study was based on a quantitative research approach and followed a single crosssectional research design. Required data were collected through a self-administered questionnaire distributed as a Google Form and the data were collected from university students (both postgraduate and undergraduate students) in Sri Lanka. Accordingly, the sample consisted of 191 university students who were chosen through the non-probabilistic convenience sampling method. The sample size is determined as per the 
guidelines of Krejcie \& Morgan, (1970).

Initially, a rigorous literature survey was performed to gather detailed information about the subject of the study, and constructs were operationalized (Farooq, et al., 2017; Venkatesh, et al., 2012) and measured with a five-point Likert scale ranging from $1=$ strongly disagree to $5=$ strongly agree. Next, to determine whether the constructs of each variable of the questionnaire can be understood by respondents, a pre-test was carried out using 20 respondents before formally circulating the questionnaire to a larger group of respondents. Two parts were included in the questionnaire. The first part, to understand the sample profile, includes socio-demographic questions while the second part assesses variables pertaining to the UTAUT-3 model.

\subsection{Data presentation and analysis}

A data cleaning process was performed to recognize outliers and missing values, before analyzing the data. Based on expert feedback and pilot test findings the questionnaire was improved and it makes it easier for respondents to respond to the questionnaire and therefore no missing values were available in the data set. Box plots have been used for the identification of outliers according to Aguinis, et al., (2013), and nine cases have been identified as outliers and removed from the database.

Afterward, factor analysis was carried out to assess the unidimensionality of the constructs. Every factor loading was significant and showed above 0.6 as recommended by (Hair, Black, Babin, \& Anderson, 2010). The normality of the data was then tested using Skewness and Kurtosis values and for the data to normally be distributed, the standard Skewness and Kurtosis values should be between +2 and 2. Accordingly, the Skewness and Kurtosis values are shown in Table 2.

AVE values were used to test the convergent validity of the data. AVE values should be more than 0.5 in accordance with the standard. The items which resulted above 0.5 satisfy the standard of AVE and they ensure the convergent validity of the data. However, intention to use elearning systems showed a result below 0.05. Hair, et al., (2010) outlined that, at this time $C R$ value can be used to evaluate the convergent validity of the instrument. Accordingly, CR values were calculated and the results were above the standard value of 0.7 . Therefore, the convergent validity of the data was ensured.

Cronbach's Alpha values were used to test the internal consistency of the data. According to the standard Cronbach's Alpha value should be higher than 0.7 . 
The results of the convergent validity and reliability tests were depicted in Table 3.

Discriminant validity indicates to what extent a given construct is diverse than other constructs (Hair, Black, Babin, \& Anderson, 2010). Consequently, average variance extracted (AVE) values of all constructs should exceed the corresponding "squared interconstruct correlation estimates (SIC)" to ensure discriminant validity. Moreover, the highest VIF value recorded by the study is 3.125, which is lower than the threshold of 10 (Hair, Sarstedt, Ringle, \& Mena, 2012). These will provide evidence to verify the absence of multicollinearity issues. Table 4 summarizes the results of the discriminant validity test and VIF values.

\subsection{Sample Profile of the Study}

The sample of the study is university students in state Sri Lankan state universities who are currently using e-learning platforms. In the sample, the majority are females $(52.9 \%)$ who are between the age of 20-25 years (37.7\%). When considering the Sri Lankan education sector in Sri Lanka, in 2019 majority of the students who are eligible and admitted to universities in Sri Lanka are females (Central Bank of Sri Lanka, 2020). Accordingly, the sample of this research was skewed towards female students. Moreover, the sample consists of $99(51.8 \%)$ postgraduates and 92 (48.2\%) undergraduates. This was to maintain the balance among undergraduate and postgraduate students.

\subsection{Mediation Analysis using Process Macro}

The model of the study which is theoretically hypothesized is tested using bootstrap-based Hayes' PROCESS macro (Hayes, 2013). The PROCESS macro is a commonly used statistical resampling method that strictly estimates parameters and defects in the model from the sample. This approach measures accurate and correct confidence intervals for indirect effects compared to the causal approach of Baron \& Kenny, (1986).

Table 6 illustrates that performance expectancy positively impacts on intention to use e-learning platforms $(\beta=$ $0.2210, t=2.6740, \mathrm{p}=0.0082)$. Moreover, facilitating conditions $((\beta=0.2001, \quad t=2.7894, \quad \mathrm{p}=$ $0.0058)$, price-value $(\beta=0.1287$, $t=2.6833, \mathrm{p}=0.0080)$, habit $(\beta=$ $0.2929, t=3.5535, \mathrm{p}=0.0005)$ and personal innovativeness in IT $(\beta=$ $0.2185, t=3.7179, \mathrm{p}=0.0003)$ also have positive impact on intention to use e-learning platforms. In addition to that effort expectancy $(\beta=0.0632, t=0.8746, p=0.3830)$ and social influence $(\beta=0.0859$, $t=1.5434, \quad \mathrm{p}=0.1245)$ have positive but insignificant impact on intention to use e-learning platforms. On the other hand hedonic motivation showed a 
negative insignificant impact on intention to use e-learning platforms $(\beta=-0.0242, t=-0.5984$, $\mathrm{p}=0.5503$ ). The $\mathrm{R}^{2}$ of the model is 0.6800 , which indicates that $68 \%$ of the variance of intention to use e-learning platforms is explained by the factors of UTAUT-3. Total effect on adoption shows 0.1306 and out of that direct effect is 0.1103 and the indirect effect is 0.0202 and all the effects are significant since the resulting confidence interval of bootstrapping does not include zero $(\mathrm{CI}=0.1028,0.3640), \quad(\mathrm{CI}=$ $0.1275, \quad 0.3482), \quad(\mathrm{CI}=0.0303$, 0.0799).

\section{DISCUSSION CONCLUSION}

AND

With the spread of Covid-19 worldwide most of the countries stopped engaging in face-to-face learning and started to operate their education system through elearning (Shahzad , Hassan, Abdullah, Hussain, \& Fareed, 2020). As the usage of e-learning platforms is a novel experience to both academics as well as students, both parties are facing numerous challenges when dealing with e-learning platforms. Academic's adoption to use elearning platforms based on the UTAUT model is tested in previous studies but student's adoption to use e-learning platforms is still an underresearched area. Considering the theoretical and contextual gap in the existing literature, this study focused on identifying the factors influencing the adoption to use e- learning platforms by Sri Lankan university students Consequently, the summary of the results obtained through the analysis is shown in Table 7i.

When considering the prior literature, the positive impact of performance expectancy on intention to use e-learning has been further proved by Sangeeta $\&$ Tandon, (2020) and Dwivedi, et al., (2019), which implies that using e-learning enhances university student's study performance. Facilitating conditions also resulted in a positive impact on intention to use e-learning platforms. Wong \& Huang, (2015) and Salloum \& Shaalan, (2019) further evidenced the positive impact of facilitating conditions on e-learning, not only in e-learning, but also in other contexts such as in mobile learning (Almaiah, Alamri, \& AlRahmi, 2019), online shopping (Javed, 2019).

Salloum \& Shaalan, (2019) and Wrycza, et al., (2017) also discuss the insignificant impact of effort expectancy on intention to use elearning platforms. On the other hand, the insignificant impact of social influence is also justified by Gunasinghe, Hamid, Khatibi, \& Azam, (2020) and Wrycza, et al., (2017). This study showed that habit has a positive impact on intention and this is consistent with the findings of Gunasinghe, et al., (2020) and El-Masri \& Tarhini, (2017). This simply means that using e-learning platforms have become a habit to university students including 
undergraduates and postgraduates as they are continuously using these platforms for more than one year and they have to be with these platforms for a considerable time period in the future as well. Moreover, price-value shows a positive impact on intention to use e-learning platforms which is consistent with the findings of Farooq, et al., (2017) and Tseng, et al., (2019).

This study resulted in a positive impact of personal innovativeness in IT on intention to use e-learning platforms which can be considered as the new addition to developing the UTAUT-3 model. However, Gunasinghe, et al., (2020) showed that personality traits like personal innovativeness in IT have an insignificant impact on the use and the adoption of elearning mechanisms. Further, it outlined that this may be due to the education level of the target respondents (Gunasinghe, Hamid, Khatibi, \& Azam, 2020). Considering this we can conclude that, as the target respondents of this study is university students who are belonging to generation $\mathrm{Z}$ are more towards new technological developments feel comfortable with e-learning systems which resulted in a positive significant impact of personal innovativeness in IT on intention to use e-learning. The undergraduate community is made up of Generation $\mathrm{Z}$ members, who are a social generation of digital natives who are technologically savvy. Their familiarity with and knowledge of digital media can be attributed to their extensive exposure to technology. During the coronavirus disease (COVID-19) pandemic, the government's adoption of e-learning in academic education may benefit such digitally capable students.

At last, as per the results obtained hedonic motivation shows a negative impact on intention to use e-learning platforms. Venkatesh, et al., (2012) outlined that the enjoyment and motivation of the user are crucial for elearning intention in higher education over the traditional way of delivery. However, regarding this study, the university students have to adjust to the e-learning platforms with the Covid-19 pandemic since they have no other option. In this situation, enjoyment might not be a crucial factor in determining intention to use e-learning. In order to intensify the impact of hedonic motivation on intention to use elearning, academia, and other responsible administrators can develop programs that are interesting to students like guest lectures on trending topics, games relating to subject matters, etc that increase the interaction between students.

\section{IMPLICATIONS OF THE STUDY}

With the Covid-19 pandemic, developed countries, as well as developing countries, are using elearning platforms to continue educational activities. But, the academic attention to identifying the university student's intention 
and adoption to use-e-learning platforms is very low. Therefore, this study will provide valuable insights into the development of both theoretical and managerial aspects of the implementation and use of e-learning systems. As mentioned, the scholarly attention to identifying the factors influencing university students' intention and adoption to use elearning platforms is very low in both global and local contexts. Therefore, this study fills the gap in the existing literature by adding knowledge on the adoption of elearning by university students in Sri Lanka, applying the UTAUT3 model. . As managerial implications, this study provides valuable insights to the administration of the universities and government to encourage students to actively participate in academic activities.

\section{LIMITATIONS AND FUTURE RESEARCH SUGGESTIONS}

This research study contains several limitations. Initially, when considering the sample of the study 191 university students in Sri Lanka is the main limitation of this study. The reason behind that is a not only university student but also school students follow their courses online at present due to the Covid-19 pandemic. As well as university students, school students are also using e-learning platforms in continuing their studies. It is worth it if future research studies focus on the adoption of e-learning by school students in Sri Lanka. Next, researchers were unable to get some important insights from university students which matter to their intention and adoption behavior to use e-learning as this study followed a quantitative approach. In the future,

researchers can follow a qualitative research approach to get important as well as interesting insights from the sample. In addition to that, the moderate effect of sociodemographic factors like gender, age, income level can be tested in future studies. 


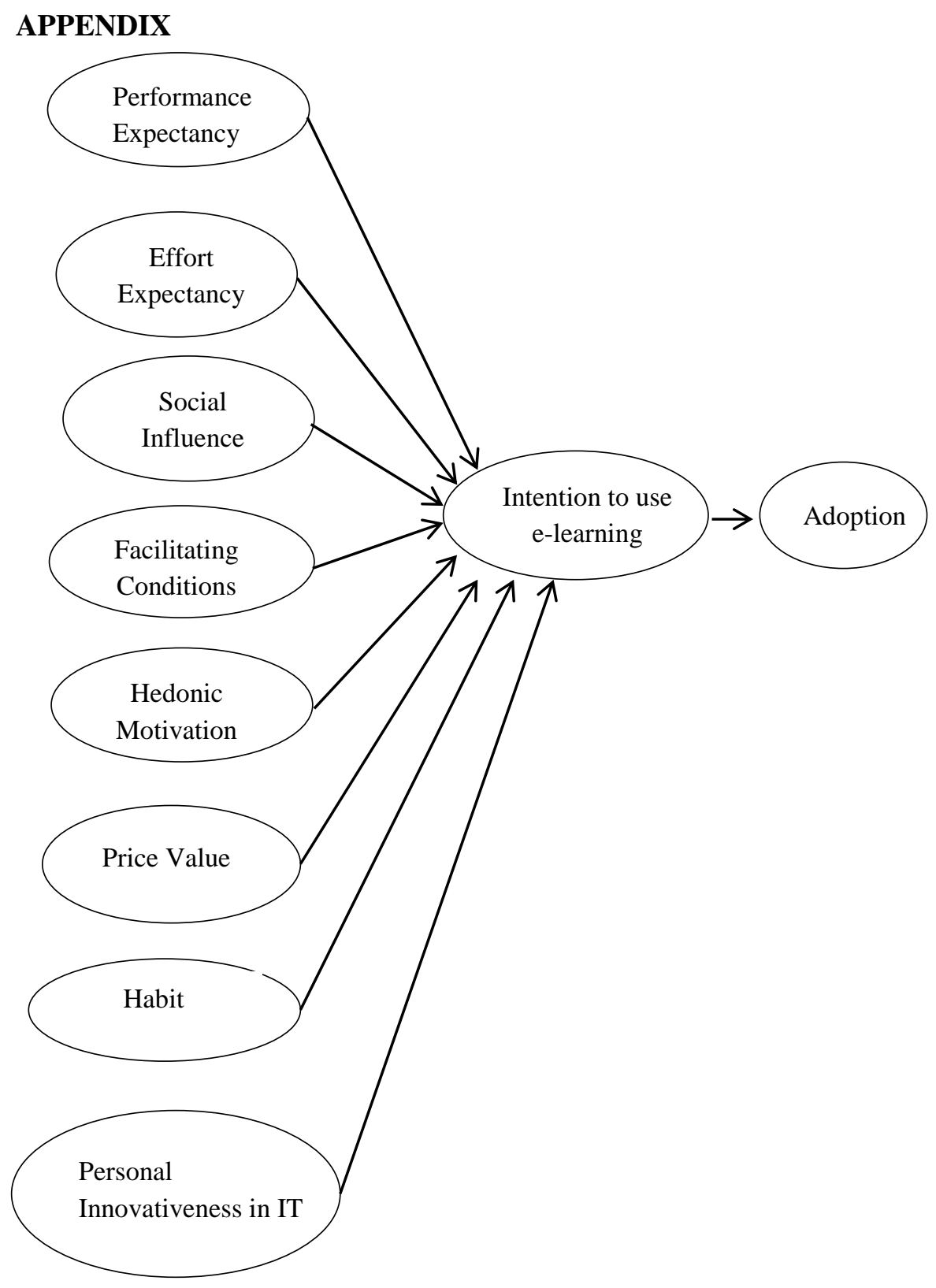

Figure 1: Conceptual framework 
Table 1: Operationalization of variables

\begin{tabular}{|c|c|c|}
\hline Variable & & Source \\
\hline PE & $\begin{array}{l}\text { PE1. Using e-learning system enables me to } \\
\text { accomplish my needs more quickly and effectively } \\
\text { PE2. Using e-learning system increases equality } \\
\text { between all students } \\
\text { PE3. Using e-learning system will save me time } \\
\text { PE4. Using e-learning system increases the quality of } \\
\text { the learning process }\end{array}$ & $\begin{array}{l}\text { (Venkates } \\
\text { h, Thong, } \\
\& \quad \mathrm{Xu}, \\
2012)\end{array}$ \\
\hline $\mathbf{E E}$ & $\begin{array}{l}\text { EE1. Learning how to use e-learning system is easy } \\
\text { for me } \\
\text { EE2. Using e-learning system in learning will be clear } \\
\text { and understandable } \\
\text { EE3. I find e-learning system easy to use } \\
\text { EE4. It is easy for me to become skillful at using e- } \\
\text { learning system }\end{array}$ & \\
\hline SI & $\begin{array}{l}\text { SI1. People who are important to me think that I should } \\
\text { use e-learning system } \\
\text { SI2. People who influence my behavior think that I } \\
\text { should use e-learning system } \\
\text { SI3. People whose opinion that I value, prefer that I use } \\
\text { e-learning system }\end{array}$ & \\
\hline FC & $\begin{array}{l}\text { FC1. I have the resources necessary to use e-learning } \\
\text { system } \\
\text { FC2. I have the knowledge necessary to use e-learning } \\
\text { system } \\
\text { FC3. e-learning system is compatible with other } \\
\text { technologies I use } \\
\text { FC4. I can get help from others when I have difficulties } \\
\text { in using e-learning system }\end{array}$ & \\
\hline HM & $\begin{array}{l}\text { HM1. Using e-learning system is fun } \\
\text { HM2. Using e-learning system is enjoyable } \\
\text { HM3. Using e-learning system is very entertaining }\end{array}$ & \\
\hline
\end{tabular}




\begin{tabular}{|c|c|c|}
\hline $\mathbf{P V}$ & $\begin{array}{l}\text { PV1. Using e-learning system is reasonable in terms } \\
\text { of money and time spent } \\
\text { PV2. Using e-learning system is cost-effective } \\
\text { PV3. e-learning system provide good value }\end{array}$ & \\
\hline HA & $\begin{array}{l}\text { HA1. The use of e-learning system has become a habit } \\
\text { for me } \\
\text { HA2. I really like to use e-learning system } \\
\text { HA3. I must use e-learning system } \\
\text { HA4. Using e-learning system has become natural to } \\
\text { me }\end{array}$ & \\
\hline PIIT & $\begin{array}{l}\text { PIIT1. I like to experiment using e-learning system } \\
\text { PIIT2. Among my peers, I am usually among the first } \\
\text { to try new ways of learning mechanism through e- } \\
\text { learning system } \\
\text { PIIT3. If I heard about a new learning mechanism like } \\
\text { e-learning system, I look for ways to experiment with } \\
\text { it } \\
\text { PIIT4. In general, I am not hesitant to try out new e- } \\
\text { learning system }\end{array}$ & $\begin{array}{l}\text { (Farooq, } \\
\text { et al., } \\
2017)\end{array}$ \\
\hline BI & $\begin{array}{l}\text { BIU1. I intent to continue suing e-learning system in } \\
\text { the future } \\
\text { BIU2. I will always try to use e-learning system in my } \\
\text { daily life } \\
\text { BIU3. I plan to continue to use e-learning system } \\
\text { frequently. }\end{array}$ & $\begin{array}{l}\text { (Tseng, } \\
\text { Lin, } \\
\text { Wang, \& } \\
\text { Liu, 2019) }\end{array}$ \\
\hline $\mathbf{B A}$ & $\begin{array}{l}\text { ELAB1. I prefer to use e-learning system } \\
\text { ELAB2. I like to use e-learning system } \\
\text { ELAB3. I am used to e-learning system now }\end{array}$ & $\begin{array}{l}\text { (Almaiah, } \\
\text { Alamri, \& } \\
\text { Al- } \\
\text { Rahmi, } \\
\text { 2019) }\end{array}$ \\
\hline
\end{tabular}


Kamalasena B.D.T.M. \& Sirisena A.B.

Wayamba Journal of Management 12 (2)

Table 2: Results of test of normality

\begin{tabular}{|l|c|c|c|c|}
\hline \multirow{2}{*}{ Performance Expectancy } & \multicolumn{2}{|c|}{ Skewness } & \multicolumn{2}{c|}{ Kurtosis } \\
\cline { 2 - 5 } & Statistic & Std. Error & Statistic & Std. Error \\
\cline { 2 - 5 } & -0.628 & 0.176 & -0.121 & 0.350 \\
\hline Effort Expectancy & -0.543 & 0.176 & -0.022 & 0.350 \\
\hline Social Influence & 0.265 & 0.176 & -0.620 & 0.350 \\
\hline Facilitating Conditions & -0.516 & 0.176 & 0.014 & 0.350 \\
\hline Hedonic Motivation & -0.119 & 0.176 & -0.513 & 0.350 \\
\hline Price Value & -0.135 & 0.176 & -0.501 & 0.350 \\
\hline Habit & -0.560 & 0.176 & 0.398 & 0.350 \\
\hline $\begin{array}{l}\text { Personal Innovativeness in } \\
\text { IT }\end{array}$ & 0.004 & 0.176 & -0.604 & 0.350 \\
\hline $\begin{array}{l}\text { Intention to use e-learning } \\
\text { systems }\end{array}$ & -0.402 & 0.176 & -0.466 & 0.350 \\
\hline Adoption & -0.559 & 0.176 & -0.364 & 0.350 \\
\hline
\end{tabular}

Source: Survey Data, 2021

Table 3: Results of convergent validity test and reliability test

\begin{tabular}{|l|c|c|c|}
\hline \multicolumn{1}{|c|}{ Variable } & AVE & CR & Cronbach's Alpha \\
\hline Performance Expectancy & 0.531 & 0.817 & 0.836 \\
\hline Effort Expectancy & 0.617 & 0.828 & 0.874 \\
\hline Social Influence & 0.568 & 0.718 & 0.714 \\
\hline Facilitating Conditions & 0.513 & 0.759 & 0.834 \\
\hline Hedonic Motivation & 0.652 & 0.849 & 0.904 \\
\hline Price Value & 0.774 & 0.911 & 0.885 \\
\hline Habit & 0.557 & 0.833 & 0.879 \\
\hline $\begin{array}{l}\text { Personal Innovativeness } \\
\text { in IT }\end{array}$ & 0.541 & 0.825 & 0.825 \\
\hline $\begin{array}{l}\text { Intention to use e- } \\
\text { learning systems }\end{array}$ & 0.452 & 0.710 & 0.900 \\
\hline Adoption & 0.712 & 0.881 & 0.908 \\
\hline
\end{tabular}

Source: Survey Data, 2021 
Kamalasena B.D.T.M. \& Sirisena A.B.

Wayamba Journal of Management 12 (2)

Table 4: Results of discriminant validity test

\begin{tabular}{|c|c|c|c|c|c|c|c|c|c|c|}
\hline & PE & EE & SI & FC & HM & PV & HA & PIIT & IN & VIF \\
\hline PE & $\mathbf{0 . 7 2 9}$ & & & & & & & & & 2.910 \\
\hline EE & 0.725 & $\mathbf{0 . 7 8 6}$ & & & & & & & & 2.814 \\
\hline SI & 0.481 & 0.510 & $\mathbf{0 . 7 5 4}$ & & & & & & & 1.488 \\
\hline FC & 0.702 & 0.690 & 0.454 & $\mathbf{0 . 7 1 6}$ & & & & & & 2.612 \\
\hline HM & - & -0.039 & -0.043 & - & $\mathbf{0 . 8 0 7}$ & & & & & 1.016 \\
\hline PV & 0.708 & 0.716 & 0.508 & 0.679 & - & $\mathbf{0 . 7 4 7}$ & & & & 3.099 \\
\hline HA & 0.231 & 0.222 & 0.152 & 0.253 & 0.006 & 0.284 & $\mathbf{0 . 8 8 0}$ & & & 1.143 \\
\hline PIIT & 0.447 & 0.453 & 0.373 & 0.490 & - & 0.552 & 0.213 & $\mathbf{0 . 6 7 3}$ & & 1.625 \\
\hline IN & 0.695 & 0.661 & 0.504 & 0.691 & - & 0.736 & 0.346 & 0.589 & $\mathbf{0 . 8 4 4}$ & 3.125 \\
\hline
\end{tabular}

Source: Survey Data, 2021

Table 5: Sample profile of the study

\begin{tabular}{|l|l|l|l|}
\hline & & Frequency & Percentage \\
\hline \multirow{5}{*}{ Gender } & Male & 90 & 47.1 \\
\cline { 2 - 4 } & Female & 101 & 52.9 \\
\cline { 2 - 4 } & Total & 191 & 100.0 \\
\cline { 2 - 4 } & Between 20-25 years & 72 & 37.7 \\
& Between 25-30 years & 40 & 20.9 \\
\cline { 2 - 4 } & Between 30-35 years & 33 & \\
\hline \multirow{5}{*}{$\begin{array}{l}\text { Following } \\
\text { degree program }\end{array}$} & Above 40 years & 20 & 17.3 \\
\cline { 2 - 4 } & Total & 26 & 10.5 \\
\cline { 2 - 4 } & Potween 35-40 years & 191 & 13.6 \\
\cline { 2 - 4 } & Potal & 92 & 100.0 \\
\cline { 2 - 4 } & Totaduates & 99 & 48.2 \\
\hline
\end{tabular}

Source: Survey Data, 2020 
Kamalasena B.D.T.M. \& Sirisena A.B.

Wayamba Journal of Management 12 (2)

Table 6: Regression results for simple mediation

\begin{tabular}{|c|c|c|c|c|}
\hline Predictor & B & SE & t value & p-value \\
\hline \multicolumn{5}{|l|}{$\begin{array}{l}\text { Intention to use } \\
\text { e-learning } \\
\text { systems (M) } \\
\end{array}$} \\
\hline Constant & -0.6272 & 0.2780 & -2.2562 & 0.0252 \\
\hline $\begin{array}{l}\text { Performance } \\
\text { Expectancy }\end{array}$ & 0.2210 & 0.0826 & 2.6740 & 0.0082 \\
\hline Effort Expectancy & 0.0632 & 0.0722 & 0.8746 & 0.3830 \\
\hline Social Influence & 0.0859 & 0.0557 & 1.5434 & 0.1245 \\
\hline $\begin{array}{l}\text { Facilitating } \\
\text { Conditions }\end{array}$ & 0.2001 & 0.0717 & 2.7894 & 0.0058 \\
\hline $\begin{array}{l}\text { Hedonic } \\
\text { Motivation }\end{array}$ & -0.0242 & 0.0405 & -0.5984 & 0.5503 \\
\hline Price Value & 0.1287 & 0.0480 & 2.6833 & 0.0080 \\
\hline Habit & 0.2929 & 0.0824 & 3.5535 & 0.0005 \\
\hline $\begin{array}{l}\text { Personal } \\
\text { Innovativeness in } \\
\text { IT }\end{array}$ & 0.2185 & 0.0588 & 3.7179 & 0.0003 \\
\hline \multirow[t]{2}{*}{ Model Summary } & $\mathrm{R}$ & $\mathrm{R}^{2}$ & p-value & \\
\hline & 0.8246 & 0.6800 & 0.000 & \\
\hline \multicolumn{5}{|c|}{ Total effect on Adoption Behavior } \\
\hline & Effect & BootSE & BootLLCI & BootULCI \\
\hline & 0.1306 & 0.1183 & 0.1028 & 0.3640 \\
\hline \multicolumn{5}{|c|}{ Direct Effect on Adoption Behavior } \\
\hline & Effect & BootSE & BootLLCI & BootULCI \\
\hline & 0.1103 & 0.1205 & 0.1275 & 0.3482 \\
\hline \multicolumn{5}{|c|}{ Indirect Effect on Adoption } \\
\hline & Effect & BootSE & BootLLCI & BootULCI \\
\hline $\begin{array}{l}\text { Intention to use e- } \\
\text { learning systems } \\
(\mathrm{M})\end{array}$ & 0.0202 & 0.0271 & 0.0303 & 0.0799 \\
\hline
\end{tabular}

Source: Survey Data, 2020 
Kamalasena B.D.T.M. \& Sirisena A.B.

Wayamba Journal of Management 12 (2)

Table 7: Summary of hypotheses testing

\begin{tabular}{|l|l|}
\hline \multicolumn{1}{|c|}{ Hypothesis } & \multicolumn{1}{|c|}{$\begin{array}{c}\text { Survey } \\
\text { findings }\end{array}$} \\
\hline $\begin{array}{l}\text { H1: Performance expectancy has a positive impact on intention to } \\
\text { use e-learning systems }\end{array}$ & Supported \\
\hline $\begin{array}{l}\text { H2: Effort expectancy has a positive impact on intention to use e- } \\
\text { learning systems }\end{array}$ & $\begin{array}{l}\text { Not } \\
\text { supported }\end{array}$ \\
\hline $\begin{array}{l}\text { H3: Social influence has a positive impact on intention to use e- } \\
\text { learning systems }\end{array}$ & $\begin{array}{l}\text { Not } \\
\text { supported }\end{array}$ \\
\hline $\begin{array}{l}\text { H4: Facilitating condition has a positive impact on intention to use } \\
\text { e-learning systems }\end{array}$ & Supported \\
\hline $\begin{array}{l}\text { H5: Hedonic motivation has a positive impact on intention to use } \\
\text { e-learning systems }\end{array}$ & $\begin{array}{l}\text { Not } \\
\text { Supported }\end{array}$ \\
\hline $\begin{array}{l}\text { H6: Price value has a positive impact on intention to use e- } \\
\text { learning systems }\end{array}$ & Supported \\
\hline $\begin{array}{l}\text { H7: Habit has a positive impact on intention to use e-learning } \\
\text { systems }\end{array}$ & Supported \\
\hline $\begin{array}{l}\text { H8: Personal innovativeness in IT has a positive impact on } \\
\text { intention to use e-learning systems }\end{array}$ & Supported \\
\hline $\begin{array}{l}\text { H9: intention to use e-learning systems has a positive impact on } \\
\text { the adoption behavior of e-learning systems }\end{array}$ & Supported \\
\hline
\end{tabular}




\section{REFERENCES}

Ekanayake, E., \& Weerasinghe, T. (2020). Sustainable Engagement of University Students in ELearning during the Postpandemic of Covid-19: Evidence from Faculty of Commerce and Management Studies, University of Kelaniya, Sri Lanka. Kelaniya Journal of Human Resource Management, 15(2), 42-73.

Wrycza, S., Marcinkowski , B., \& Gajda, D. (2017). The Enriched UTAUT Model for the Acceptance of Software Engineering Tools in Academic Education. Information Systems Management, 34(1), 38-49.

Aguinis, H., Gottfredson, R., \& Joo, H. (2013). BestPractice

Recommendations for Defining, Identifying, and Handling Outliers Organizational Research Methods, 16(2), 270-301.

Ajzen, I. (1991). The theory of planned behavior. Organizational Behavior and Human Decision Processes, 50(2), 179211.

Al-Azawei, A., \& Lundqvist, K. (2015). Learner differences in perceived satisfaction of an online learning: an extension to the technology acceptance model in an arabic sample. Electron Journal of e-Learning, 13(5), 408-426.

Almaiah, M. A., Alamri, M. M., \& Al- Rahmi, W. (2019). Applying the UTAUT Model to Explain the Students' Acceptance of Mobile Learning System in Higher Education. IEEE Access, 174673174686.

Andersson , A. (2008). Seven major challenges for elearning in developing countries: Case study eBIT, Sri Lanka. International Journal of Education and Development using Information and Communication Technology, 4(3), 45-62.

Baron, R., \& Kenny, D. (1986). The moderator-mediator variable distinction in social psychological research: Conceptual, strategic, and statistical considerations. Journal of Personality and Social Psychology, 1173-1182.

Basak, S., Wotto, M., \& Belanger, P. (2018). E-learning, Mlearning and Dlearning:Conceptual definition and comparative analysis. $E$ - 
Learning and Digital Media, 15(4), 191-216.

Bateman, P. J., Gray, P. H., \& Butler, B. S. (2011). The Impact of Community Commitment on Participation in Online Communities. Information Systems Research, 22(4), 841854.

Bennett, S., Maton, K., \& Kervin, L. (2008). The 'digital natives' debate: a critical review of the evidence. British Journal of Educational Technology, 39(5), 775-786.

Central Bank of Sri Lanka. (2020). Economics and Social Statistics of Sri Lanka. Colombo: Statistics Department, Central Bank of Sri Lanka.

Chen, C., \& Lin, P. (2016). Development and evaluation of a contextaware ubiquitous learning environment for astronomy education. Interactive Learning Environments, 24(3), 644-661.

Chen, M., Wang, X., Wang, J., \& Zuo, C. (2021). Factors Affecting College Students' Continuous Intention to Use Online Course Platform. SN Computer Science.
Davis, F. (1986). A technology acceptance model for empirically testing new end-user information systems: theory and results. Sloan School of Management,Massachuse tts Institute.

Davis, F., Bagozzi, R., \& Warshaw, P. (1992). Extrinsic and intrinsic motivation to use computers in the workplace. Journal of Applied Social Psychology, 22(14), 1111-1132.

Dhawan, S. (2020). Online learning: A panacea in the time of COVID-19. Journal of Educational Technology Systems, 49(1), 5-22.

Dutta, D., Gwebu, K., \& Wang, J. (2015). Personal innovativeness in technology, related knowledge and experience, and entrepreneurial intentions in emerging technology industries: a process of causation or effectuation? International

Entrepreneurship and Management Journal, 11(3), 529-555.

Dwivedi , Y. K., Rana, N. P., Jeyaraj, A., Clement, M., \& Williams, M. D. (2019). Re-examining the Unified Theory of Acceptance and Use of 
Technology (UTAUT):

Towards a Revised

Theoretical Model. Inf Syst Front, 719-734.

El-Masri, M., \& Tarhini, A. (2017). Factors affecting the adoption of e-learning systems in Qatar and USA: extending the unified theory of acceptance and use of technology 2 (UTAUT2). Educational Technology Research and Development, 65(3), 743763.

Farooq, M., Salam, M., Jaafar, N., Fayolle, A., Ayupp, K., Radovic-Markovic, M., \& Sajid, A. (2017). Acceptance and use of lecture capture system (LCS) in executive business studies: extending UTAUT2. Interactive Technology and Smart Education, 14(4), 329-348.

Fishbein, M., \& Ajzen, I. (1975). Belief, Attitude, Intention and Behavior: An Introduction to Theory and Research. AddisonWesley Reading,MA.

Gunasinghe, A., Hamid, J. A., Khatibi, A., \& Azam, S. F. (2020). The adequacy of UTAUT-3 in interpreting academician's adoption to e-Learning in higher education environments. Interactive Technology and Smart Education, 17(1), 86-106.

Hair, J., Black, W., Babin, B., \& Anderson, R. (2010). Multivariate Data Analysis. Upper Saddle River: NJ: Prentice-Hall, Inc.

Hair, J., Sarstedt, M., Ringle, C., \& Mena, J. (2012). An assessment of the use of partial least squares structural equation modeling in marketing research. Journal of the academy of marketing science, 40(3), 414-433.

Hayes, A. (2013). Introduction to Mediation, Moderation, and Conditional Process Analysis: A RegressionBased Approach. New York: The Guilford Press.

Hodges, C., Moore, S., Lockee, B., Trust, T., \& Bond, A. (2020). The difference between emergency remote teaching and online learning. EDUCAUSE Review.

Javed, B. (2019). The Role of Online Shopping Service Quality in e-Retailing towards Online Shopping Intention: Testing the moderation mechanism in UTAUT. Pakistan Journal of Commerce and Social Sciences, 13(3), 680-703. 
Krejcie , R. V., \& Morgan, D. W. (1970). Determining Sample Size for Research Activities. Educational and Psychological Measurement, 607-610.

Krejcir, R. V., \& Morgan, D. W. (1970). Determining Sample Size for Research Activities. Educational and Psychological Measurement, 30, 607610.

Kuem, J., Khansa, L., \& Kim, S. S. (2020). Prominence and Engagement: Different Mechanisms Regulating Continuance and Contribution in Online Communities. Journal of Management Information Systems, 37(1), 162-190.

Kulikowski, K., Przytuła, S., \& Sułkowski, L. (2021). Elearning? Never again! On the unintended consequences of COVID19 forced e-learning on academic teacher motivational job characteristics. Higher Education Quarterly, 116.

Lai, H. (2018). Investigating older adults' decisions to use mobile devices for learning, based on the unified theory of acceptance and use of technology. Interactive Learning Environments.
Leonardi, P. (2020). You're going digital-now what? MIT Sloan Management Review, 61(2), 28-35.

Liaw , S. (2008). Investigating students' perceived satisfaction, behavioral intention, and effectiveness of elearning: a case study of the Blackboard system. Computer Education, 864-873.

Little, R., \& Rubin, D. (2002). Statistical Analysis with Missing Data. New York: John Wiley and Sons.

Mei, B., Brown, G., \& Teo, T. (2018). Toward an understanding of preservice English as a foreign language teachers' acceptance of computer assisted language learning 2.0 in the People's Republic of China. Journal of Educational Computing Research, 56(1), 74-104.

Moore, G., \& Benbasat, I. (1991). Development of an instrument to measure the perceptions of adopting an information technology innovation. Information Systems Research, 2(3), 192-222.

Mosunmola, A., Mayowa, A., Okuboyejo, S., \& Adeniji, C. (2018, January). Adoption and use of mobile learning in higher 
education: The UTAUT model. Proceedings of the 9th International Conference on EEducation. E-Business, $E$ Management and $e$ Learning, 20-25.

Murray, K., \& Häubl, G. (2007). Explaining cognitive lock-in: the role of skillbased habits of use in consumer choice. Journal of Consumer Research, 34(1), 77-88.

Olasina, G. (2019). Human and social factors affecting the decision of students to accept e-learning. Interactive Learning Environments, 27(3), 363-376.

Patil, P., Tamilmani, K., Rana, N. P., \& Raghavan, V. (2020). Understanding consumer adoption of mobile payment in India: Extending Meta-UTAUT model with personal innovativeness, anxiety, trust, and grievance redressal. International Journal of Information Management.

Perera, R., \& Udunuwara, M. (2021). Effect of Social Media Marketing on Purchase Intentions of Women's Clothing and Accessories. THE American Journal of Humanities and Social Sciences Research, 4(2), 22-33.
Salloum, S. A., \& Shaalan, K. (2019). Factors Affecting Students' Acceptance of E-Learning System in Higher Education Using UTAUT and Structural Equation Modeling Approaches. Proceedings of the International Conference on Advanced Intelligent Systems and Informatics 2018 (pp. 469-480). Springer Nature: Switzerland.

Sangeeta, \& Tandon, U. (2020). Factors influencing adoption of online teaching by school teachers: A study during COVID-19 pandemic. Journal of Public Affairs, 1-11.

Sangra, A., Vlachopoulos, D., \& Cabrera, N. (2012). Building an inclusive definition of E-learning: An approach to the conceptual framework. International Review of Research in Open and Distance Learning, 13(2), 145-159.

Saxena, K. (2020). Coronavirus accelerates pace of digital education in India.

Shahzad , A., Hassan, R., Abdullah, N., Hussain, A., \& Fareed, M. (2020). COVID-19 impact on ecommerce usage: An empirical evidence from Malaysian healthcare industry. Humanities \& 
Social Sciences Reviews, 8(3), 599-609.

Shahzad, A., Hassan, R., Aremu, A., Hussain, A., \& Lodhi, R. (2021). Effects of COVID-19 in E-learning on higher education institution students: the group comparison between male and female. Quality \& quantity, 55(3), 805-826.

Sohail, M. S., \& Hasan, M. (2020). The Impact of Social Media Marketing on Brand Trust and Brand Loyalty:An Arab Perspective. International Journal of Online Marketing, 10(1), 15-31.

Sulkowski, L. (2020). Covid-19 pandemic; recession, virtual revolution leading to de-globalization? Journal of Intercultural Management, 12(1), 111.

Tan, P. (2013). Applying the UTAUT to understand factors affecting the use of English elearning websites in Taiwan. Sage Open.

Taylor, S., \& Todd, P. (1995). "Understanding information technology usage: a test of competing models. Information Systems Research, 6(2), 144-176.
Thompson, R., Higgins, C., \& Howell, J. (1991). Personal computing: toward a conceptual model of utilization. MIS Quarterly, 15(1), 125143.

Tian, F., Zheng, Q., \& Chao, K. (2020). Current and future of technologies and services in smart elearning. Service Oriented Computing and Applications, 14, 1-3.

Tseng, T., Lin, S., Wang, Y., \& Liu, H. (2019). Investigating teachers' adoption of MOOCs: The perspective of UTAUT2. Interactive Learning Environments, 1-16.

UNESCO Report. (2020). COVID-19 educational disruption and response. UNESCO.

Venkatesh, V., Morris, M., Davis, G., \& Davis, F. (2003, September). User acceptance of information technology: Toward a unified view. MIS Quart, 1(3), 425-478.

Venkatesh, V., Thong, J., \& Xu, $X$. (2012). Consumer acceptance and use of information technology: extending the unified theory of acceptance and use of technology. MIS Quarterly, 12(1), 157178. 
Venkatesh, V., Thong, J., \& Xu, X. (2016). Unified theory of acceptance and use of technology: A synthesis and the road ahead. Journal of the Association for Information Systems, 17(5), 328-376.

Wang, Y., Wu, M., \& Wang, H. (2009). Investigating the determinants and age and gender differences in the acceptance of mobile learning. Br. Journal of Education Technology, 40(1), 92-118.

Wheeler, S. (2012). e-Learning and digital learning. Encyclopedia of the Sciences of Learning, 1109-1111.

Wong, W., \& Huang, N. (2015). The effects of e-learning system service quality and users' acceptance on organizational learning. International Journal of Business Information, 6(2), 205-225.

Yoo, S., Han, S., \& Huang, W. (2012). The roles of intrinsic motivators and extrinsic motivators in promoting e-learning in the workplace: a case from South Korea. Computarized Humun Behavior, 28(3), 942950.

Zhang, W., Wang, Y., Yang, L., \& Wang, C. (2020). Suspending classes without stopping learning: China's education emergency management policy in the COVID-19 outbreak. Journal of Risk and Financial Management, 13(3), 55. 